\title{
MONOTEISME TEORITIS DALAM RITUAL KEDUK BEJI DI KABUPATEN NGAWI (KAJIAN SOSIO-RELIGI)
}

\author{
Novi Triana Habsari \\ Program Studi Pendidikan Sejarah FKIP Universitas PGRI Madiun \\ trianahabsari86@gmail.com
}

\begin{abstract}
Abstrak
Tulisan ini untuk mengetahui prosesi ritual Keduk Beji di Sendang Tawun Desa Tawun Kecamatan Kasreman Kabupaten Ngawi dan apakah sampai sekarang masyarakat masih menganut Monoteisme teoritis dalam ritual keduk Beji. Lokasi penelitian adalah di Desa Tawun Kecamatan Kasreman Kabupaten Ngawi. Penelitian ini adalah penelitian kualitatif dengan jenis studi kasus. Teknik pengambilan data dengan metode wawancara, observasi, dan dokumentasi. Teknik pengumpulan sampel dengan snowball sampling. Sumber data yang digunakan adalah sumber data primer dan sumber data sekunder. Validasi yang dipergunakan untuk menguji kebenaran data yaitu trianggulasi sumber. Analisis data yang digunakan adalah analisis data model interaktif Miles dan Huberman dengan 3 tahapan, yaitu reduksi data, sajian data dan verifikasi. Berdasarkan hasil penelitian bahwa masyarakat Desa Tawun termasuk ke dalam penganut kepercayaan monoteisme teoritis. Mereka mempercayai bahwa Tuhan itu Esa dalam teori, tetapi prakteknya mereka mempercayai lebih dari satu Tuhan. Pelaksanaan ritual diadakan hari Selasa Kliwon setiap tahun pada bulan suro. Ritual Jawa identik dengan sesajen, sama halnya dengan Keduk Beji. Acara diawali dengan pengedukan atau pembersihan sendang. Kemudian dilanjutkan penyilepan dimana juru kunci melakukan penyelaman ke dalam sendang untuk meletakan kendi di dasar sendang dan mengambil kendi yang pernah ditaruhnya setahun lalu. Diakhiri dengan pertunjukan Tari Kecetan, dan kenduri (selamatan). Makna filosofis Ritual Keduk Beji adalah mengajarkan tentang kebersihan dan peduli terhadap lingkungan sekitar.
\end{abstract}

Kata Kunci : Monoteisme teoritis, Ritual, Sosio-Religi

\begin{abstract}
This paper is to know the procession of ritual Keduk Beji in Sendang Tawun Tawun Village Kasreman District of Ngawi District and whether until now people still embrace theoretical monotheism in Beji's rituals. The research location is in Tawun Village, Kasreman District, Ngawi District. This research is a qualitative research with case study type. Technique of taking data by interview method, observation, and documentation. Sampling technique with snowball sampling. Data source used is primary data source and secondary data source. Validation used to test the truth of data that is source triangulation. Data analysis used is interactive data model analysis Miles and Huberman with 3 stages, namely data reduction, data presentation and verification. Based on the results of research that Tawun villagers belong to the believer theoretical monotheism. They believe that God is one in theory, but in practice they believe in more than one God. Implementation of the ritual is held on Tuesday Kliwon every year on suro month. Javanese rituals are synonymous with offerings, just as with Beji Beji. The event begins with spreading or cleaning. Then continued pengilepan where the caretaker dive into the spring to put the jug on the bottom of the jug and picked up the jug that he had put a year ago. Ends with a show of Kecetan Dance, and kenduri (Selamatan). The philosophical significance of Keduk Beji Ritual is to teach about hygiene and care for the environment.
\end{abstract}

Keywords: Theoretical Monotheism, Ritual, Socio-Religion 


\section{PENDAHULUAN}

Aset budaya yang tersebar di seluruh wilayah Indonesia memberi nuansa keanekaragaman corak adat dan ritual. Menurut Panuti Sudjiman (1984: 76), ritual adalah buah pikiran, kepercayaan, adat istiadat, pandangan hidup, yang diturunkan secara lisan dari satu generasi ke generasi berikutnya. Masyarakat meyakini dan mempercayai keberadaannya.

Seiring dengan perkembangan peradaban dan kebudayaan manusia, berbagai macam bentuknya pun masih tetap hidup terpelihara serta dijalani oleh masyarakat sampai dengan saat sekarang. Salah satu bentuk kegiatan ritual religius Jawa yang menarik untuk dikaji adalah ritual ritual yang dilaksanakan di Desa Tawun Kecamatan Kasreman Kabupaten Ngawi yaitu ritual Keduk Beji. Seperti yang dikatakan oleh Kusnaka Adimihardja (1983: 48) bahwa kata "religi" merupakan terjemahan langsung dari bahasa asing Religion, biasa diterjemahkan dalam bahasa Indonesia dengan perkataan "agama”, yang berkaitan dengan sistem kepercayaan masyarakat yang masih hidup sampai saat ini. Selain untuk melestarikan adat istiadat, ritual Keduk Beji juga sebagai media interaksi sosial antar masyarakat. Hal tersebut diwujudkan saat prosesi selamatan, dimana seluruh warga desa berkumpul menjadi satu. Komunikasi serta pembicaraan terjalin satu sama lain tanpa membedakan status sosial. Sedangkan menurut Soerjono Soekanto (2001: 67), interaksi sosial merupakan hubungan sosial yang dinamis menyangkut hubungan antara orang dengan perorangan, antara kelompok dengan manusia, maupun antara orang perorangan dengan kelompok manusia. Sama halnya dengan interaksi yang terjadi pada saat Ritual Keduk Beji berlangsung, dimana semua anggota masyarakat makan bersama setelah diadakan selamatan.

Dinamakan Keduk Beji karena Keduk berarti membersihkan, sedangkan Beji merupakan nama sendang yang dibersihkan. Jadi dapat diuraikan bahwa Keduk Beji merupakan acara pembersihan Sendang Beji. Hal menarik dari acara ini adalah dengan dibuatnya serentetan acara atau prosesi menurut adat Jawa sebelum pembersihan sendang dimulai. Masyarakat setempat meyakini bahwa sendang Beji merupakan tempat sakral. Di sebelah Sendang Beji terdapat juga makam leluhur dari Desa Tawun sehingga sangat dikeramatkan bahkan terdapat mitos berkembang hingga sekarang. Menurut pendapat Harsojo (1984 : 228) sistem mitos dari suku - suku bangsa biasanya berisi mengenai dua hal yaitu ; 1). Kosmologi, atau penjelasan yang lengkap mengenai alam semesta, 2). Kosmogoni, yang berisi tentang 
penciptaan dan asal usul manusia. Sedangkan mitos yang masih berkembang di Desa Tawun yakni kosmologi Jawa. Hal ini berkaitan dengan sistem kepercayaan dan pemikiran Jawa. Hal tersebut memiliki kesamaan persepsi dengan masyarakat desa Tawun, mereka menganggap suatu tempat tertentu memiliki kekuatan gaib. Salah satu contoh nyatanya yakni masyarakat Desa Tawun meyakini bahwa di Sendang Tawun terdapat satu kekuatan mistis yang yang cukup kuat. Inilah yang membuat tempat tersebut dikeramatkan.

Masyarakat Desa Tawun termasuk ke dalam penganut kepercayaan monoteisme teoritis. Mereka mempercayai bahwa Tuhan itu Esa dalam teori, tetapi di dalam praktek mereka mempercayai lebih dari satu Tuhan. Mereka beranggapan bahwa mereka menempati dunia ini berrsamasama dengan banyak roh. Selain itu, terdapat satu keterkaitan proses gerakan alam dengan gerakan ro-roh tersebut. Mereka juga mempercayai bahwa manusia memiliki jiwa yang bisa meninggalkan tempatnya dan memasuki makluk lain. Animisme merupakan suatu pemikiran yang tidak hanya memberikan penjelasan atau suatu fenomena saja, tetapi memungkinkan manusia memahami keseluruhan dunia. Dari sisi dinamisme mereka percaya bahwa benda atau materi memiliki kesamaan sifat dengan manusia. Misalnya, api memiliki sifat yang sama dengan manusia. Api memiliki kekuatan untuk membunuh atau melenyapkan apapun dengan panasnya. Sebagaimana manusia mampu membunuh dengan kekuatan tangannya. Karena itulah api dipercaya memiliki roh. Sama halnya dengan keberadaan air di dalam sendang. Maka dari itulah perlu diadakannya suatu penghormatan. Proses tersebut dilakukan agar tidak terjadi sesuatu yang tidak diinginkan.

Koentjaraningrat (1997: 347), mengungkapkan bahwa orang Jawa percaya kepada suatu kekuatan yang melebihi segala kekuatan di mana saja yang pernah dikenal, yaitu kesakten, kemudian arwah atau ruh leluhur, dan makluk-makluk halus seperti misalnya memedi, lelembut, tuyul, demit serta jin dan lainnya yang menempati alam sekitar tempat tinggal mereka. Ada beberapa mitos yang masih hidup ditengah-tengah masyarakat Desa Tawun. Mitos yang pertama berkenaan dengan kedudukan Juru Kunci. Orang yang terpilih menjadi juru kunci adalah merupakan anak turun dari nenek moyang Desa Tawun. Mereka bertugas sebagai penyilep atau penyeberang sesaji. Apabila orang lain yang melakukan tugas itu, konon orang tersebut akan tertimpa petaka. Mitos lain yang berhubungan dengan ritual tersebut yakni mengenai kelengkapan 
sesaji. Menurut Soerjanegara (1995:18), bahwa ritual atau adat istiadat adalah merupakan peraturan petunjuk hidup yang tumbuh dan berasal dari masyarakat sekitar, seperti menghormati orang tua atau guru. Ritual berkaitan erat dengan sistem religi yang dianut oleh masyarakat.

Religi merupakan terjemahan langsung dari bahasa asing Religion, diterjemahkan dalam bahasa Indonesia dengan perkataan "agama", yang berkaitan dengan sistem kepercayaan masyarakat yang masih hidup sampai saat ini (Kusnaka Adimihardja, 1983: 48). Emile Durkheim dalam Anthony Giddens, dkk (2005:49) meyakini bahwa religi adalah hal paling primitif dari segala fenomena sosial. Semua manifestasi lain dalam aktivitas kolektif berasal dari agama dan melalui berbagai transformasi secara berturut-turut, antara lain: menyangkut hukum, moral, seni, bentuk politik dan sebagainya. Menurut Budiono Herusanto (2008: 42), pada prinsipnya religi adalah penyerahan diri manusia kepada Tuhan, dalam keyakinan bahwa manusia itu tergantung dari Tuhan, bahwa Tuhanlah yang merupakan keselamatan yang sejati dari manusia, bahwa manusia dengan kekuatannya sendiri tidak mampu untuk memperoleh keselamatan itu dan karenanya ia menyerahkan dirinya. Sistem religi orang jawa tidak dapat dilepaskan dengan adanya mitos yang berkembang dalam masyarakatnya. Manusia mempercayai berbagai kekuatan diluar dirinya yang memiliki daya yang luar biasa dalam mengendalikan kehidupan mereka. Menurut Harsojo (1986: 228) fungsi mitos adalah untuk mengkondifikasikan, memberikan dukungan dan memberikan landassan kebenaran dari kepercayaan ritualonal dan tingkah laku. Jika salah satu jenis sesaji tidak ada atau tidak lengkap, maka niscaya air yang telah dibersihkan tidak dapat jernih dan terus menerus keruh. Tulisan ini akan menjelaskan tentang konteks monoteisme teoritis dalam ritual keduk beji dalam sudut pandang sosio-religi.

\section{METODE PENELITIAN}

Lokasi penelitian ini dilaksanakan di Desa Tawun Kecamatan Kasreman Kabupaten Ngawi. Desa Tawun merupakan desa yang letaknya tidak jauh dari Kota Ngawi. Penelitian dilakukan pada bulan Mei hingga September 2017. Pendekatan ini menggunakan metode kualitatif. Metode kualitatif adalah prosedur penelitian yang menghasilkan data deskriptif seperti ucapan atau tulisan dan perilaku yang dapat diamati dari orang-orang itu sendiri (Arief Furchan, 1992:21-22). Jenis penelitian yang digunakan adalah jenis studi kasus. Husaini Usman mengemukakan bahwa penelitian kasus adalah penelitian yang digunakan untuk 
mempelajari latar belakang keadaan sekarang, dan interaksi suatu sosial, individu, kelompok, lembaga dan masyarakat (Husaini Usman, 2004:5). Jenis sumber data yang digunakan dalam penelitian ini adalah Sumber Data Primer berupa infomasi yang berasal dari juru kunci Sendang Tawun, kepala Desa Tawun, perangkat Desa Tawun, serta masyarakat sekitar Sendang Beji. Sedangkan Sumber data Sekunder berupa sumber-sumber.

Dalam penelitian ini peneliti mengambil 15 sampel dari seluruh jumlah penduduk Desa Tawun untuk dijadikan sebagai bahan penelitian. Teknik Pengumpulan Sampel teknik snowball sampling atau teknik penentuan sampel bola salju. Teknik pengumpulan data dalam penelitian ini menggunakan beberapa teknik yaitu wawancara, observasi dan dokumentasi. Jenis wawancara yang dipilih oleh peneliti yaitu jenis wawancara terpimpin atau wawancara yang menggunakan konsep wawancara. Jenis observasi yang dipilih peneliti yakni observasi non-partisipan. Jenis dokumentasi yang dipilih dalam penelitian ini yaitu dokumentasi primer dan dokumentasi sekunder. Dokumentasi primer diperoleh melalui asil observasi dan hasil wawancara. Sedangkan dokumentasi sekundernya berupa profil Desa Tawun, serta foto-foto prosesi Keduk Beji, dan dokumen serta bahan statistik Desa Tawun. Validitas dapat diperoleh melalui trianggulasi Jenis trianggulasi yang dipakai dalam penelitian ini yaitu jenis trianggulasi data atau biasa disebut dengan trianggulasi sumber. Cara ini mengarahkan peneliti agar didalam mengumpulkan data, ia wajib menggunakan beragam sumber data yang tersedia. Analisis data yang digunakan adalah analisis interaktif yaitu proses analisi dimana peneliti tetap bergerak diantara tiga komponen yakni reduksi data, sajian data dan verifikasi. Langkah analisis data dapat disajikan dalam bagan 1 berikut ini:

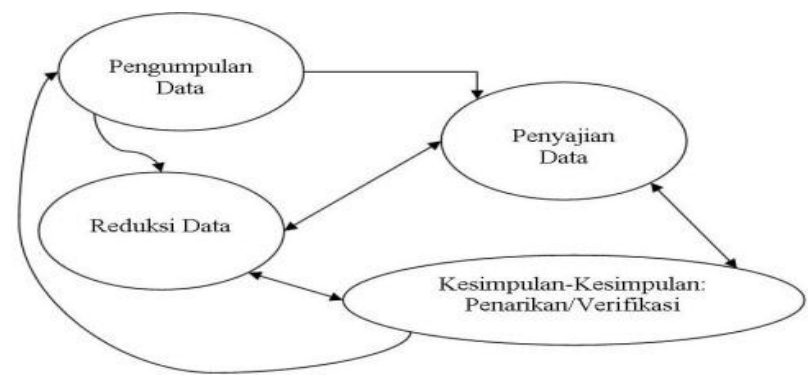

Bagan 1: Model Analisis Kualitatif Model Interaktif Miles dan Huberman (Miles dan Huberman, 2009: 20) 


\section{HASIL DAN PEMBAHASAN}

\section{Hasil Penelitian}

\section{Asal Mula Ritual Keduk Beji}

Pada abad ke-15 di derah Padas (sekarang menjadi Kasreman) terdapat seorang pengembara yang berhasil menemukan sendang. Pengembara itu bernama Ki Ageng Metawun. Kemudian masyarakat setempat menamakan sendang itu dengan nama Desa Tawun. Nama tersebut diambilkan dari nama belakang Ki Ageng Metawun. Beliau mengembara bersama istri dan seorang putra Sultan Pajang yang bernama Raden Hasaryo (wawancara, Supomo, 23/05/2012). Istri Ki Ageng Metawun bernama Nyai Ageng Ketawang. Mereka hidup damai dan dikaruniai dua orang anak laki-laki yang bernama Ludrojoyo dan Seconegoro. Radeng Ludrojoyo memiliki kegemaran bertani sedangkan Raden Seconegoro lebih suka belajar keprajuritan, olah perang dan mendalami ilmu ketatanegaraan. Raden Seconegoro berguru pada Raden Hasaryo yang ikut menetap bersama Ki Ageng Tawun.

Setelah dewasa Raden Seconegoro ikut mengabdi ke Kesultanan Pajang bersama Raden Hasaryo. Beliau dibekali sebuah cinde pusaka oleh ayahnya pada saat terjadinya pertempuran antara Kesultanan Pajang dengan Kerajaan Blambangn. Kesultanan Pajang menuai kemenangan di bawah pimpinan Raden Seconegoro. Berkat jasanya beliau diangakat sebagai senopati perang oleh Sultan Pajang. Lain cerita dengan Raden Ludrojoyo. Beliau sangat memperhatikan rakyat kecil serta petani. Pada saat itu para petani tidak dapat menanam padi dengan sempurna dikarenakan kekurangan air walaupun terdapat sendang di desa itu. Raden Ludrojoyo tidak habis pikir. Beliau selalu selalu mencari jalan keluar serta cara untuk dapat mengalirkan air sendang menuju persawahan warga. Keterbatasan air tersebut dikarenakan sawah-sawah para petani letaknya lebih tinggi dibandingkan dengan letak sendang. Pada saat itu sistem pengairan modern seperti saat ini sehingga mereka bingung untuk mengalirkan air sendang menuju sawah.

Sampai pada suatu hari tepatnya hari Kamis Kliwon Raden Ludrojoyo mengutarakan niatnya untuk bertapa matirto kepada ayahnya. Matirto adalah ulah tirakat atau bertapa dengan cara merendam diri di dalam air. Di Jawa bertapa seperti ini juga dikenal dengan sebutan topo kungkum. Bertapa ini dilakukan dengan cara merendam seluruh tubuh sebatas leher atau bahu di dalam air. Dengan bertapa matirto beliau berharap cita-cita luhurnya akan dikabulkan oleh Tuhan pencipta alam semesta. Raden Ludrojoyo berniat meminta petunjuk kepada Tuhan agar diberikan cara untuk mengalirkan air sendang ke sawah-sawah para petani. 
Ayahnya pun mengabulkan niat mulia anaknya tersebut. Tepat pukul tujuh malam malam Jumat Legi, Raden Ludrojoyo pergi ke Sendang Beji. beliau berdoa sambil merendam dirinya dii sendang tersebut. Semula suasana malam tersebut terlihat cerah. Namun tepat pada pukul dubelas malam suasana berubah menjadi menyeramkan. Tiba-tiba cahaya bulan meredup tertutup awan tebal. Tak lama kemudian terdengar suara ledakan yang keras. Ledakan tersebut sampai membangunkan warga desa. Mereka beramai-ramai menuju pusat ledakan yang diduga berasal dari Sendang Beji. Raden Ludrojoyo yang sebelumnya Bertapa di tempat tersebut tiba-tiba menghilang. Sendangkan Sendang dari tempat asal menuju ke sebelah utara. Sendang tersebut berpindah ke tempat yang lebih tinggi dari sawah penduduk.

Ki Ageng Metawun dibantu oleh masyarakat terus mencari putranya di dalam sendang sampai hari Selasa Kliwon. Akan tetapi beliau tidak menemukannya. Raden Ludrojoyo tetap tidak diketemukan meskipun air sendang telah dikuras bersih (obsevasi, 24/05/2012). Untuk mengenang peristiwa hilangnya Raden Ludrojoyo, maka setahun sekali warga setempat mengadakan tadisi Keduk Beji secara turun temurun. tersebut untuk mengenang pengorbanan Raden Ludrojoyo putra Ki Ageng Metawun yang peduli terhadap kaum petani yang menderita.

\section{Prosesi Keduk Beji}

Ritual Keduk Beji biasa digelar setelah masa panen pada hari Selasa Kliwon setiap tahunnya. (wawancara Sukarno, 19/5/2012). Untuk bulan pelaksanaan tergantung kesepakatan tokoh masyarakat dan perangkat desa. Biasanya, menyesuaikan dengan usai masa panen raya petani. Mengingat banyak penduduk yang masih menganut kepercayaan Jawa kuno, maka pengambilan hari tersebut dipercaya karena merupakan hari baik berdasarkan kalender Jawa. (observasi, 24/05/2012)

Ada sepuluh perlengkapan sesaji yang wajib dipersiapkan sebelum berlangsung. (observasi, 19/05/2012)

a. Cok bakal yang berisi telur, beras, garam, kencur, cabe merah, bawang merah, bawang putih, dan terasi, daun sirih kemenyan madu gondo arum

b. Kembang gantal (kembang warnawarni), sekar telin gondo wangi (kembang telon)

c. Panggang ayam tulak rojo muka (ayam panggang), Golong angesti tunggal (golong jumlah sembilan), Tumpeng Gono Bahu alelawuh sayur/jejanganan adem ayem (tumpeng setinggi \pm 2 meter dan sayuran) 
d. Pisang ayu apupus cinde (pisang rojo apupus ijo)

e. Jenang panca warna (bubur warna lima: putih berarti suci, merah berarti hawa nafsu, kuning berarti senang, hitam berarti kuat dan hijau berarti manunggal)

f. Arang-arang kambang (dawet ketan juruh)

g. Pudak ripih widodaren (raja tatukulan/hasil bumi)

h. Kambing guling.

Tata urutan Keduk Beji berlangsung selama lima hari berturut-turut. Prosesi diselenggarakan dari hari Kamis Kliwon sampai dengan Selasa Kliwon. Dimulai dari hari Kamis Kliwon pukul 15.00 WIB sampai selesai yakni berupa acara selamatan panggang tumpeng. Selamatan dilakukan di kediaman para keturunan asli Tawun. Pada hari Jumat Legi dilakukan acara selamatan bersama. Seluruh masyarakat dari empat dukuh berkumpul di Sarehan Sentono pada pukul 14.00 WIB. Hari berikutnya masyarakat setempat mengadakan acara gugur gunung di lingkungan Sumber Beji. acara ini dilaksanakan pada hari Sabtu Pahing. Masyarakat bergotong royong membersihkan lingkungan desa. Minggu Pon seluruh tidak ada acara apapun di Desa tawun (wawancara Supari, 23/05/2012).

Hari Senin Wage membuat gunungan di halaman Sumber Beji. memasang hiasan janur-janur di Pendopo Sumber Beji. Jam 17.00 WIB juru silem membuka untuk mandi bersama warga dan kepala desa beserta stafnya sampai dengan malam Rabu Legi untuk umum. Hari Selasa Kliwon jam 05.00 WIB sesaji dari rumah Kepala Desa dibawa ke Sumber Beji beserta kambing Kendit. Sebelum penyembelihan kambing diadakan selamatan pada dini hari. Kemudian kambing dimandikan, disembelih, dikuliti lalu dipanggang. Semua bumbu serta jerohan kambing dimasukin kembali ke dalam perut kambing. Selain kambing ada juga sesaji yang harus disiapkan (wawancara Dedi, 24/05/2012).

Puncak acara yakni pada hari Selasa Kliwon. Pada pukul 09.00 WIB masyarakat berbondong-bondong melaksanakan bersih desa di sekitar Sendang Beji dan lingkungan obyek wisata Tawun. Acara dilanjutkan dengan pengedukan atau pembersihan Sendang Beji. Prosesi keduk beji diawali dengan mandi lumpur dan menguras sendang atau pembersihan kotoran di dalam sendang Beji. Seluruh pemuda desa terjun ke air sumber untuk mengambil sampah dan daun-daun yang mengotori kolam dalam setahun terakhir. (observasi, 19/05/2012). Pada pukul 24.00 WIB ritual dilanjutkan dengan ritual penyilepan acara ini merupakan pusat dari seluruh acara. Disini juru kunci atau silem yang mengambil peran. 
Orang yang dipilih untuk menyilep adalah orang dari keturunan sesepuh Desa Tawun. Selain orang-orang tersebut dilarang keras untuk menyelam ke dalam sendang. Konon apabila orang asing tersebut ikut menyelam, maka ia tidak akan bisa keluar dari dasar sendang.

Sebelum menyilem atau menyelam ke dasar sendang Juru Kunci dirias. Tubuhnya dilumuri bedak dan diberi penanda janur di lengan dan kepala serta mengenakan pakaian kebesaran. Setelah membakar dupa dan membaca mantra tertentu, dilakukan mbukak sumber, yakni juru kunci diiringi warga menyelam selama beberapa menit ke dasar sendang Tawun. la menyelam sambil memasukan sesaji yang berupa air badheg (air tape ketan) yang ditaruh didalam kendi kecil ke dalam pusat sumber. (wawancara, Pranowo, 21/5/2012)

Inti dari ritual Keduk Beji terletak pada penyilepan atau penyimpanan kendi di pusat sumber air Beji yang terdapat di dalam sebuah gua. Untuk menuju sumber air, juru silep yang telah ditunjuk harus menyelam ke dalam air guna menuju gua, tetapi sebelumnya diawali dengan ritual pembacaan doa. (wawancara, Suryo Wirawan, 19/5/2012). Setelah acara penyilepan usai, warga desa dihibur dengan tarian Langen Bekso atau biasa dikenal dengan tarian Gambyong. Para penari diiringi dengan gamelan menari bersama masyarakat setempat. Pada saat itu juga sang Juru Kunci bertugas mengecek apakah sumber sudah jernih atau masih keruh. Keesokan harinya, tepatnya pada hari Rabu Legi diadakan pertunjukan tari Kecetan atau cambuk berdarah. Pada acara ini terdapat dua orang lakilaki saling mencambuki satu sama lain. Tidak jarang para penari tersebut mengalami luka-luka. Saat ini terian tersebut telah dikembangkan oleh Dinas Kebudayaan sebagai salah satu tarian khas daerah Kabupaten Ngawi.

Seusai pertunjukan tari Kecetan, acara dilanjutkan dengan makan bersama Gunungan Lanang dan Gunungan Wadon yang telah disediakan bagi warga untuk ngalub (meraih) berkah. Warga saling berebut makanan yang dipercaya bisa mendatangkan berkah dan keberuntungan bagi kehidupannya kelak. Kemudian acara berikutnya yakni selamatn bersama yang diadakan persis di sebelah timur Sendang Beji. Acara Kadek Beji ditutup dengan pertunjukan tari Langen Bekso yang diselenggarakan di kediaman Kepala Desa. Seluruh warga datang untuk memeriahkan acara itu. Selain warga setempat, tidak sedikit para petinggi daerah menghadiri acara tahunan tersebut (wawancara, Sutarno, 18/5/2012).

\section{Makna Filosofis Keduk Beji}


Ritual Dhuk atau Keduk Beji Tawun ini selain merupakan rasa syukur pada Sang Pencipta dan menghormati arwah leluhur. Banyak hal yang menjadi keistimewaan dari Ritual Keduk Beji, terutama dalam hal-hal filosofis yang melingkupinya. Makna filosofi tergambar melalui ritual pembersihan kolam dan pemberian sesaji yang merupakan ungkapan syukur akan berkah yang telah diberikan dari sumber air tersebut. Dari segi sosiologis, Ritual Keduk Beji di Desa Tawun mempunyai makna sebagai wadah interaksi sosial yang dapat membina solidaritas sosial antara masyarakat Sarangan dan dengan pejabat pemerintah. Adapun nilai edukatif dalam mitos dan ritual ini adalah nilai moral, nilai adat (ritual), dan nilai sejarah (observasi, 23/05/2012).

Hal lain yang juga menarik adalah ketika dua penyilem (penyelam) mengganti kendi. Makna penyilan atau penyelaman ini dimaksudkan agar kendi yang ada di dalam sendang bisa diganti setiap tahun. Dari penggantian kendi ini secara tidak langsung air sendangpun juga diganti sehingga kebersihan airnya dapat terjaga. Pada saat penyilepan para peserta ritual lainnya tidak hanya berdiam diri, melainkan mereka melakukan ritual Tari Kecetan (Tari Pukul). Tarian ini dimulai dengan memukulkan kayu ke air kolam, namun kemudian akan dilanjut dengan saling pukul antar peserta. Tidak jarang beberapa penari akan terbawa emosi dan mengakibatkan cedera. Namun, hal tersebut bermakna lebih dalam dari apa yang terlihat karena meskipun terjadi baku pukul, usaha pelampiasan emosi tersebut hanya terjadi selama pelaksanaan ritual tersebut. Setiap peserta dapat saling melepaskan kegelisahan terhadap sesama warga desa. Seusai ritual, segenap warga akan saling bermaafan dan memulai kehidupan yang baru.(wawancara, Santoso, 24/05/2012).

Selain kegiatan-kegiatan, ada hal lain yang tidak kalah penting pemaknaan simbolisnya yaitu sesaji tumpeng. Kehadiran tumpeng dalam ritual selametan pada budaya Jawa memberi makna yang mendalam, begitupun dalam komponen-komponen tumpeng itu sendiri. Nasi tumpeng yang berbentuk kerucut ditempatkan di tengah-tengah dan bermacam-macam lauk pauk disusun di sekeliling kerucut tersebut. Penempatan nasi dan lauk pauk seperti ini disimbolkan sebagai gunung dan tanah yang subur di sekelilingnya. Tanah di sekeliling gunung dipenuhi dengan berbagai macam sayuran dari tumbuh-tumbuhan dan lauk-pauk. Itu semua sebagai simbol atau tanda yang berasal dari alam, hasil tanah. Tanah menjadi simbol kesejahteraan yang hakiki. Penempatan dan pemilihan lauk-pauk dalam tumpeng 
juga didasari akan pengetahuan dan hubungan mereka dengan alam. Oleh karena itulah lauk-pauk ditempatkan di sekeliling nasi karena memang dari sanalah mereka berasal (wawancara, Sipin, 25/05/2012).

\section{Pembahasan}

\section{Langkah-Langkah Keduk Beji}

Pelaksanaan ritual ini dimulai dengan pengerukan atau pembersihan kotoran di dalam sumber Beji. Seluruh pemuda desa terjun ke sumber mata air untuk mengambil sampah dan daundaun yang mengotori kolam dalam setahun terakhir. Proses ini diwarnai dengan mandi lumpur oleh para pemuda yang terjun ke air. Sumber air ini digunakan untuk menyuplai air kolam renang di tempat wisata Tawun dan untuk mengairi lahan pertanian penduduk sekitar setiap tahunnya.

Usai membersihkan kolam, dua penyelam (tukang silem) yang mengenakan pakaian adat Jawa, masuk ke dalam kolam tersebut. Kedua penyelam yang merupakan keturunan tukang silem ini membawa sebuah kendi berisi air badhek (air tape) yang dianggap sebagai air suci. Sedangkan para peserta ritual yang ada di dalam kolam mengikuti irama sinden. Peserta tua maupun muda masing-masing memegang tongkat kayu menarikan Tari Kecetan (Tari Pukul) di dalam kolam.

Ritual ditutup dengan makan bersama Gunungan Lanang dan
Gunungan Wadon yang telah disediakan. Warga saling berebut makanan yang dipercaya bisa mendatangkan berkah dan keberuntungan bagi kehidupannya kelak. adat ditutup dengan aksi warga yang mengambil air untuk diminum atau mandi, karena dipercaya akan memberikan berkah bagi kehidupan mereka, berupa kesehatan dan kemurahan rezeki. Mereka percaya bahwa makanan yang berasal dari kedua gunungan tersebut dapat berkah.

Dampak Ritual Keduk Beji Ditinjau Dari Aspek Sosiologi

\section{a. Perubahan Karakter Masyarakat}

Dalam ritual keagamaan seperti , masyarakat mengukuhkan kembali dirinya ke dalam perbuatan simbolik sebagai sarana bagi kelompok sosial tersebut untuk secara periodik mengukuhkan kembali dirinya. Hal ini berarti secara tidak langsung melalui pelaksanaan, maka akan tercipta suatu bentuk solidaritas sosial di antara para penganutnya. Pada harihari biasa masyarakat terlihat lebih individual. Namun dengan adanya ritual tersebut masyarakat terlihat lebih akrab rasa kekeluargaan mereka pun juga lebih tinggi.

Keduk Beji ini, merupakan salah satu cara untuk melestarikan adat budaya penduduk Desa Tawun sejak jaman dulu. Disamping itu ritual Keduk Beji dilakukan dengan tujuan memperoleh solidaritas sosial. 
tersebut juga menumbuhkan rasa kerja sama yang tinggi. dalam berbagai kesempatan, ritualonal dilaksanakan dengan melibatkan banyak orang. Hal inilah yang akhirnya menimbulkan rasa gotong royong yang tercipta antar anggota masyarakat. Bukti kebersamaan warga desa terlihat saat seluruh pemuda desa terjun ke kolam untuk mengeluarkan kotoran dari dalam sumber mata air yang bernama Beji.

\section{b. Tumbuhnya Kembali Adat Ritual}

Bentuk sistem masyarakat Jawa pada dasarnya terdiri dari msyarakat kekeluargaan dan masyarakat berketuhanan. Pada masa lalu, sistem hidup kekeluargaan di jawa tergambar dalam hukum adatnya. Adat istiadat dimana setiap individu membantu individu lain dalam hal-hal tertentu. Pada masa kini sisa-sisa dari semangat kebersamaan yang merupakan salah satu adat Jawa tersebut dilanda oleh modernisasi. Hal ini mengakibatkan dasar-dasar kemasyarakatan lama harus menyesuaikan diri dengan perkembangan jaman. Adat istiadat (ritual) semakin banyak ditinggalkan.

Namun demikian, sisa-sisa kearifan lokal masyarakat ritualonal Jawa sebagian masih ada yang diberlakukan oleh sebagian masyarakat Desa Tawun. Wujud nyata realisasinya biasanya dalam bentuk acara-acara seremonial. Hal ini memiliki dampak yang besar khusunya bagi masyaraka desa. Salah satu diantaranya yaitu menghidupkan kembali sifat hidup gotong royong. Selain itu tarjaganya kembali pola hidup kekeluargaaan agar tetap dihargai dan bernilai guna sebai kelanjutan dari naluri ritual yang tetap harus dipertahankan dari generasi ke generasi berikutnya.

\section{c. Menumbuhkan Integrasi Sosial}

adat juga memiliki peranan penting dalam mewujudkan integrasi sosial. Hubungan di antara masyarakat penganutnya akan munculnya solidaritas berkawan atas dasar kesamaan adat dan kepercayaan, hingga akan mempertemukan dan menyatukan mereka meskipun dari kelompok dan stratifikasi sosial yang berbeda-beda.

Masyarakat Desa Tawun memiliki tiga jenis aliran yakni aliran abangan, netral, dan islam fanatik. Dari ketiga jenis aliran ini semuanya mendukung adanya acra ritual tersebut, mereka beranggapan bahwa Ritual keduk beji ini merupakan suatu warisan yang perlu dijaga eksistensinya. Jadi diantara mereka semua, tidak satupun yang menetang adanya ritual tersebut.

Dalam setiap penyelenggaraan merupakan pernyataan tingkat pemikiran yang efektif dari dua atau 
beberapa orang, sebagai pernyataan solidaritas dan perwujudan kebaikan hati orang-orang yang terlibat dalam tersebut. Jika dianalogikan, Keduk Beji tak ubahnya sebagai sebuah magnet yang akan menarik setiap orang yang memiliki hubungan keluarga dan keturunan penduduk asli desa setempat. Sekalipun mereka telah menetap di luar daerah, mereka secara otomatis akan pulang setiap bulan Safar untuk turut menyelenggarakan acara tersebut. Jadi tidaklah mengherankan bila dalam pelaksanaan acara seringkali ditemukan para peserta yang datang dari desa lain.

Dari beberapa pandangan informan maka dapat dikatakan bahwa secara sosiologis keberadaan Keduk Beji ini memberikan fungsi positif bagi masyarakat sebagai sarana untuk mewujudkan solidaritas sosial masyarakat setempat.

Dampak Ritual Keduk Beji Ditinjau Dari Aspek Religi

a. Penggabungan Animisme dan Dinamisme Mennjadi Monoteisme

Para penganut monoteisme beranggapan bahwa hanya ada satu tuhan bagi mereka. Tuhan tersebut mencipta, memelihara dan kemudian menghancurkan alam semesta ini. Dialah penguasa tunggal yang berada dan berasal dari luar alam semesta ini.
Dalam masyarakat yang sudah maju, kepercayaan yang dianut bukan lagi dinamisme ataupun animisme tetapi kepercayaan monoteisme. Sedangkan kepercayaan monoteisme terdiri dari empat jenis yakni monoteime praktis, monoteisme spekulatif, monoteisme teoritis, dan monoteisme murni. Masyarakat Desa Tawun termasuk ke dalam penganut kepercayaan monoteisme teoritis. Mereka mempercayai bahwa Tuhan itu Esa dalam teori, tetapi di dalam praktek mereka mempercayai lebih dari satu Tuhan. Mereka beranggapan bahwa mereka menempati dunia ini berrsama-sama dengan begitu banyak roh. Selain itu terdapat satu keterkaitan proses gerakan alam dengan gerakan ro-roh tersebut. Mereka juga mempercayai bahwa manusia memiliki jiwa yang bisa meninggalkan tempatnya dan memasuki makluk lain. Animisme merupakan suatu pemikiran yang tidak hanya memberikan penjelasan atau suatu fenomena saja, tetapi memungkinkan manusia memahami keseluruhan dunia.

Sedangkan dari sisi dinamisme mereka percaya bahwa benda atau materi memiliki kesamaan sifat dengan manusia. Sebagai contoh, api memiliki sifat yang sama dengan manusia. Api memiliki kekuatan 
untuk membunuh atau melenyapkan apapun dengan panasnya. Sebagaimana manusia mampu membunuh dengan kekuatan tangannya. Karena itulah api dipercaya memiliki roh. Sama halnya dengan keberadaan air di dalam sendang. Maka dari itulah perlu diadakannya suatu penghormatan. Proses tersebut dilakukan agar tidak terjadi sesuatu yang tidak diinginkan.

b. Menanamkan Nilai Positif Kepercayaan Jawa

Sejarah perkembangan religi orang Jawa telah dimulai sejak jaman prasejarah. Pada waktu itu nenek moyang orang Jawa sudah beranggapan bahwa semua benda yang ada di sekelilingnya itu bernyawa. Semua yang bergerak dianggap hidup dan mempunyai kekuatan gaib atau mempunyai roh yang berwatak baik maupun jahat. Dengan dasar anggapan demikian mereka membayangkan dalam anganangan mereka bahwa disamping segala roh yang ada tentulah ada roh yang paling berkuasa dan lebih kuat dari manusia. Untuk menghindarkan ganguan dari roh itu maka mereka memuja-mujanya dengan jalan mengadakan .

Pemujaan arwah nenek moyang ialah agama mereka yang pertama. Arwah nenek moyang pernah hidup telah banyak jasa dan pengalamannya. Dengan demikian mereka perlu meminta berkah dan petunjuk dari arwah nenek moyang tersebut. Sarana yang ditempuh untuk mendatangkan arwah nenek moyang ialah dengan cara mengadakan. Sisa religius seperti tersebut diatas sampai sekarang masih ada dalam kehidupan masyarakat Jawa Khususnya masyarakat Desa Tawun. Namun saat ini telah berubah fungsinya kesenian rakyat ritualonal. salah satunya yaitu ritual Keduk Beji.

Pelaksanaan dirumuskan sebagai sebuah bentuk perwujudan dari nilai kepercayaan Jawa yang dianut oleh masyarakat karena motif religi bisa menjadi salah satu tendensi penting dilaksanakannya sebuah ataupun ritual bagi masyarakat. Salah satu motif pelaksanaan adalah motif agama religius, dimana tiap acara memiliki sifat magis dan religious, karena merupakan warisan leluhur yang dalam pandangan masyarakat menduduki posisi setara dengan dewa. Hal itu dilaksanakan demi memperoleh berkah dan kemurahan.

Kepercayaan merupakan bagian yang sangat fundamental bagi manusia, dan hal tersebut bisa tergambar dari seberapa mampu seseorang atau suatu komunitas menerapkannya dalam wujud konkrit yang telah diuraikan sebelumnya. 
Kepercayaan atau nilai suatu agama akan mengantarkan anggota masyarakat menjadi mahluk sosial. Agama melestarikan masyarakat, memelihara di hadapan manusia dalam arti memberi nilai bagi manusia, menanamkan sifat dasar manusia.

Kepercayaan

masyarakat tersebut diatas dilandasi karena adanya keyakinan yang dimiliki oleh masyarakat setempat. Sebagai manifestasi dari agama dan kepercayaan yang dianut oleh masyarakat, juga tentunya memiliki fungsi sosial bagi masyarakat sebagai pengokoh kekuatan moral. Setiap masyarakat bisa tetap eksis dan survive karena sikap kooperatif dari anggota-anggotanya. Sifat kooperatif antarwarga masyarakat itu sendiri diperoleh melalui jalur sosialisasi, dan agama adalah sumber utama proses sosialisasi yang dimaksud. Karena itu, agama berperan memberiiikan sokongan psikologis. Agama selain membantu orang lain dari kebingungan dunia dan menawarkan jawaban tentang berbagai permasalahan, juga memberiiikan kekuatan moral

\section{c. Memberikan Kekuatan Moral}

Dari uraian di atas, dapat difahami bahwa sebagai sebuah bagian dari kepercayaan yang dianut oleh masyarakat dan diwujudkan dalam riual adat, Keduk Beji diyakini bisa memberikan kekuatan moral bagi masyarakat untuk berlindung kepada Sang Penguasa dari berbagai hal-hal yang tidak diinginkan. Masyarakat yang memegang erat nilai modal sosial dalam acara tersebut mempercayai bahwa apabila kegiatan itu tidak dilaksanakan, maka akan terjadi sesuatu yang buruk yang akan menimpa masyarakat.

Setiap keganjilan dan hal-hal yang dianggap tidak sesuai dengan keinginan dan kebetulan menimpanya selalu dikaitkan dengan perayaan Keduk Beji tersebut. Menurut kesaksian dari beberapa informan apabila tersebut dilakukan tanpa memeperhatikan kelengkapan acara yang diperlukan, maka tidak jarang akan terjadi hal-hal yang diluar keinginan masyarakat. Satu hal yang pernah terjadi apabila peralatan acara tidak lengkap adalah air yang keluar dari dasar sendang terus menerus keruh.

\section{d. Menumbuhkan Rasa Kepedulian} Terhadap Lingkungan

Ritual keduk Beji merupakan salah satu tindakan simbolis dalam religi sebagai sisa peninggalan jaman mitos. Pemberian sesaji pada sumber air dan pohon besar yang ada di pinggir sendang merupakan salah satu buktinya. Maksud diselenggarakannya sesaji ialah untuk mendukung 
kepercayaan mereka terhadap kekuatan makluk-makluk halus. Selain itu juga untuk meminta berkah dan lindungan dari penghuni tempat tersebut serta sebagi bukti penghormatan mereka. Selain itu, tujuan diadakannya yakni merupakan suatu ajakan yang secara tidak langsung untuk menjaga lingkungan sekitar.

ritual Keduk Beji dilakukan demi mencapai keteteraman hidup lahir batin. Dengan mengadakan ritual itu, masyarakat Desa Tawun telah memenuhi kebutuhan spiritualnya. Kehidupan rohani mereka memang bersumber dari ajaran agama yang telah diberi hiasan budaya lokal. Oleh karena itu, orientasi kehidupan keberagamaan mereka senantiasa memperhatikan nilai-nilai luhur yang telah diwariskan oleh nenek moyangnya.

Sebagai sebuah ritual agama Keduk Beji ini adalah sebuah ekspresi sejarah yang juga tidak bisa telepas dari nilai-nilai religiusitas. Jadi sebagai sebuah warisan budaya, acara ini juga menyimpan makna tersirat sebagai sarana yang berfungsi sebagai media komunikasi agama dan spiritual. Hal ini sebagai bentuk pengejawantahan rasa syukur masyarakat akan berbagai anugrah yang diperoleh selama hidupnya.
Keinginan luhur masyarakat untuk mengungkapkan rasa syukur ini terwujud dalam beberapa ritual adat yang diselenggarakan pada acara puncak , antara lain prosesi pembuatan berbagai makanan khas yang menunjukkan rasa syukur masyarakat akan potensi alam yang dianugrahkan oleh Sang Penguasa alam semsesta.

Selain sebagai ungkapan rasa syukur kepada Tuhan Yang Maha Esa, Keduk Beji ini juga diyakini oleh masyarakat setempat sebagai ajang untuk memohon perlindungan kepada arwah leluhur dari berbagai ancaman dan malapetaka yang bisa saja menimpa mereka. Menurut masyarakat setempat, ia mempercayai acara ini sebagai perlindungan dan tolak bala.

\section{PENUTUP}

Simpulan

Berdasarkan penelitian yang telah dilaksanakan, dapat ditarik kesimpulan bahwa Keduk Beji merupakan salah bentuk peninggalan kebudayaan Jawa. Acara diawali dengan pengedukan atau pembersihan sendang. Para pemuda menjegurkan ke kolam yang ada Sendang Beji dengan tujuan membersihkan kotoran dedaunan juga mengeduk lumpur. Setelah secara beramai-ramai melakukan pembersihan terhadap kolam yang ada sendang, 
diteruskan dengan penyilepan dimana juru kunci melakukan penyelaman ke dalam sendang untuk meletakan kendi dan mengambil kendi yang pernah ditaruhnya setahun yang lalu. Dan diakhiri dengan penyiraman air legen ke sumber Bedji yang diikuti penyeberangan sesaji dari timur kolam ke barat kolam. Dari aspek sosiologi, Keduk Beji bermanfaat untuk mempererat tali persaudaraan serta menghidupkan kembali sifat hidup gotong royong antar warga. Dengan adanya acara ini seluruh masyarakat melebur menjadi satu tanpa memandang stratifikasi sosial mereka. Selain dari aspek sosiologi, ada pula dampak religi Keduk Beji yakni mengambil makna positif dari kepercayaan Jawa yang terkandung dalam proses. Salah satu makna filosofis yang terdapat dalam Keduk Beji yakni upaya untuk melestarikan lingkungan alam.

\section{Saran}

\section{Masyarakat Desa Tawun}

Sebagai warisan budaya, ritual Keduk Beji semestinya di transformasikan kepada generasi selanjutnya agar semacam ini bisa terjaga eksistensinya hingga masa yang akan datang.

\section{Pemerintah Desa Tawun}

Peneliti menaruh harapan besar kepada seluruh pihak dalam pelaksanaan acara keduk Beji untuk menjunjung tinggi nilai yang dianut oleh masyarakat dan menjaga warisan kearifan lokal.

3. Dinas Pariwisata Dan Kebudayaan Kabupaten Ngawi

Peneliti menaruh harapan besar kepada segenap elemen yang berperan dalam promosi budaya, khususnya kepada pemerintah agar memfasilitasi kegiatan Keduk Beji agar pesta adat ini dapat di publikasikan secara lebih luas.

\section{DAFTAR PUSTAKA}

Anthony Giddens. dkk. 2005. Sosiologi Sejarah Dan Berbagai Pemikirannya. Yogyakarta : Kreasi Wacana

Arief Furchan. 1992. Pengantar Metoda Penelitian Kualitatif Suatu Pendekatan Fenomenologis terhadap Ilmu-Ilmu Sosial. Surabaya : Usaha Nasional

Budiono Herusatoto. 1984. Simbolisme Dalam Budaya Jawa. Yogyakarta : PT. Hanindita

Miles Dan Huberman. 1992. Analisis Data Kualitatif. Terjemahan Oleh Tjetjep Rohendi Rohidi. 2009. Jakarta : Universitas Indonesia.

Harsojo. 1984. Pengantar Antropologi. Binacipta

Harsojo. 1986. Pengantar Antropologi. Binacipta

Husaini Usman dan Purnomo Setiadi Akbar. 2004. Metode Penelitian Sosial. Jakarta : PT. Bumi Aksara 
Koentjaraningrat. 1997. Manusia Dan Kebudayaan di Indonesia. Jakarta : Djambatan

Kusnaka Adimihardja. 1983. Kerangka Studi Antropologi Sosial Dalam Pembangunan. Bandung : Tarsito

PanutiSudjiman.1984. Kamus Istilah Sastra. Jakarta : PT. Gramedia

Soerjono Soekanto. 2001. Sosiologi

Suatu Pengantar. Jakarta : PT. Raja Grafindo Persada 